\title{
Abundance, behavior and entomological inoculation rates of anthropophilic anophelines from a primary Colombian malaria endemic area
}

\author{
Nelson Naranjo-Diaz', Doris A Rosero ${ }^{1}$, Guillermo Rua-Uribe², Shirley Luckhart ${ }^{3}$ and Margarita M Correa ${ }^{1 *}$
}

\begin{abstract}
Background: In Colombia for several years, the Urabá-Bajo Cauca and Alto Sinú region has registered the highest numbers of malaria cases in the country. Malaria vector incrimination and the characterization of entomological parameters will allow for a better understanding of malaria transmission dynamics and the design of effective vector control strategies for this region.
\end{abstract}

Methods: We conducted a longitudinal survey between November 2008 and June 2010 to quantify entomological (abundance and biting activity) and transmission parameters, including infection rate (IR) and entomological inoculation rate (EIR), to incriminate potential anopheline vectors in three localities of a major Colombian malaria endemic region, the Urabá-Bajo Cauca and Alto Sinú: La Capilla, Juan Jose and El Loro.

Results: A total of 5,316 anopheline mosquitoes corresponding to seven species were collected. Anopheles nuneztovari (69.5\%) and Anopheles darlingi (22.2\%) were the most abundant species, followed by Anopheles pseudopunctipennis (4.5\%), Anopheles albitarsis s.l. (2\%), Anopheles triannulatus lineage Northwest (1.8\%), Anopheles punctimacula and Anopheles argyritarsis (at $<1 \%$, each). Three species were naturally infected with Plasmodium vivax, An. nuneztovari, An. darlingi (IRs $<1 \%)$ and An. triannulatus (IR = 1.5\%). Annual EIRs for these species ranged from 3.5 to 4.8 infective bites per year.

Conclusions: These results indicate that An. nuneztovari and An. darlingi continue to be the most important malaria vectors in this region. Anopheles triannulatus, a species of local importance in other South American countries was found naturally infected with Plasmodium vivax VK247; therefore, further work should be directed to understand if this species has a role in malaria transmission in this region.

Keywords: Malaria vectors, Infection rate, Human biting rate, Entomological inoculation rate, Colombia

\section{Background}

Colombia ranks second in number of malaria cases in Latin America and, in the past two decades with few exceptions, more than 100,000 cases were registered annually [1]. For several years, the Urabá-Bajo Cauca and Alto Sinú (UCS) region has had the highest numbers of malaria cases in the country [2], registering $58.18 \%$ of the total cases in 2010 [3]. Further, Plasmodium vivax has historically been the most prevalent species in UCS, causing $76.11 \%$ and $88.26 \%$ of the cases in 2010 and

\footnotetext{
* Correspondence: mcorrea@quimbaya.udea.edu.co

'Grupo de Microbiología Molecular. Escuela de Microbiología, Universidad de Antioquia, Medellín, Colombia

Full list of author information is available at the end of the article
}

2011, respectively [3,4]. It is likely, however, that these case numbers are an underestimate of both transmission and clinical disease $[5,6]$.

Among the approximately 47 anopheline species that have been identified in Colombia [7], the three main vector species, Anopheles albimanus Wiedemann, Anopheles nuneztovari Gabaldon and Anopheles darlingi Root, are present in UCS, together with local vectors of importance in other Colombian regions including Anopheles pseudopunctipennis Theobald, Anopheles punctimacula Dyar \& Knab, Anopheles oswaldoi (Peryassu) and Anopheles rangeli Gabaldon [7-10]. Some of these species are sibling species with overlapping characters or belong to a complex of cryptic species that differ in their ability to

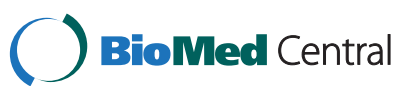


support parasite development, further complicating their incrimination in transmission [11]. For example, within the Albitarsis Complex, six species have been formally described [12-15] and Ruiz et al. [16] have recently proposed three new members. Within this species complex, only Anopheles deaneorum Rosa-Freitas [17-19], Anopheles marajoara Galvão \& Damasceno [20] and Anopheles albitarsis E [21], renamed as Anopheles janconnae Wilkerson \& Sallum [14], have been described as epidemiologically important in Brazil. In Colombia, a new mtDNA COI gene lineage closely related to Anopheles janconnae (subsequently named Anopheles albitarsis I [16]) was detected in localities of UCS [22], but its importance in malaria transmission is unknown. Similarly, Anopheles triannulatus is a complex of at least three species, including Anopheles triannulatus s.s. (Neiva \& Pinto), Anopheles halophylus Silva-do-Nascimento \& Lourenço-de-Oliveira, and Anopheles triannulatus $\mathrm{C}$ (undescribed) [23,24]. In addition, the primary malaria vector $A n$. nuneztovari is frequently confused with other species of the Oswaldoi Group due to intraspecific variation and overlapping morphology of the adult [25-28]. Indeed, it has been suggested that $A n$. nuneztovari is a species complex [29-32] and based on white and $C O I$ gene sequence analyses, this complex may be composed of at least two cryptic species, $A n$. nuneztovari s.s. located in Colombia and Venezuela and An. goeldii Rozeboom \& Gabaldon and other possible species or lineages present in the Amazon basin [29,31,33]. In Colombia, An. nuneztovari was reported infected with Plasmodium sp. in Bajo Calima, Buenaventura [34], and more recently, with Plasmodium vivax VK247 in Montelibano and Tierralta localities in UCS [8].

In Brazil, An. triannulatus at high densities appears to contribute to transmission at the local level [35] and has been reported infected with Plasmodium falciparum, $P$. vivax and Plasmodium malariae Grassi \& Felletiin in the Amazon region [35-37]. This species was also considered the dominant vector in eastern Loreto, Peru [38]. In Colombia, An. triannulatus has a wide distribution and in some northwestern localities it was among the predominant species [8], showing either anthropophilic behavior or zoophilic tendencies [8,39]. However, until the present study, An. triannulatus had not been reported infected with Plasmodium spp. in endemic areas of Colombia.

Previous studies conducted in UCS attempted to increase knowledge of anopheline species behavior [40] and relative importance in malaria transmission [8]. However, these studies were constrained in the number and frequency/seasonality of collection days, which can limit detection of variation in anopheline behavior. Therefore, we conducted a longitudinal survey between November 2008 and June 2010 to assess temporal differences in anopheline behavior and transmission parameters in three UCS localities that have not been evaluated in previous studies.

\section{Methods \\ Study sites}

The sites sampled were (1) El Loro-LOR, in the Tierralta municipality, (2) Juan Jose-JUJ in Puerto Libertador, Cordoba Department, and (3) La Capilla-CAP, in El Bagre municipality, Antioquia Department (Figure 1, Table 1). In general, the primary economic activities in UCS are smallscale agriculture and livestock production. Activities in LOR and CAP sampled sites also include timber extraction and artisanal open sky gold mining, respectively.

\section{Mosquito collection}

Collections were conducted from November 2008 to June 2010 using human-landing catches, under an informed consent agreement and collection protocol reviewed and approved by a University of Antioquia Institutional Review Board (Comité de Bioética Sede Investigación Universitaria, CBEIH-SIU, UdeA, approval document 07-41-082). Each locality was visited four times, once every three months. Indoor and outdoor collections within $\sim 10 \mathrm{~m}$ of the house were conducted regularly by four human baits per shift (two indoors and two outdoors), from 18:00-24:00 h during five days and one additional night from 18:00-06:00 h. For some species it was possible to obtain and rear field-collected larvae to support species identification. Adult mosquitoes and immature stages were identified using morphology based keys $[7,42,43]$. Species presenting difficulties during the taxonomic identification were confirmed by PCR-RFLP-ITS2 [25,27,44] and COI barcode strategy [45] using primers of Folmer et al. [46].

\section{Detection of Plasmodium infected mosquitoes}

Enzyme-linked immunosorbent assay (ELISA) was conducted with pools of up to five heads and thorax of mosquitoes of the same species to ensure 99\% confidence of detecting at least one infected mosquito per pool (expected $<2 \%$ ) [8,39]. The initial ELISA was conducted using three monoclonal antibodies directed to P. falciparum, P. vivax VK247 and VK210, tested on separate plates $[8,39,47,48]$. Positive pools were confirmed by a second ELISA and a nested PCR with Plasmodium genus-specific primers $[8,39,49]$ using $6 \mu \mathrm{L}$ of DNA extracted from individual abdomens as the template [50]. The PCR analysis served to verify the infected mosquito(s) in the pool.

\section{Entomological parameters}

The infection rate (IR) was calculated as the percentage of Plasmodium positive mosquitoes out of the total 


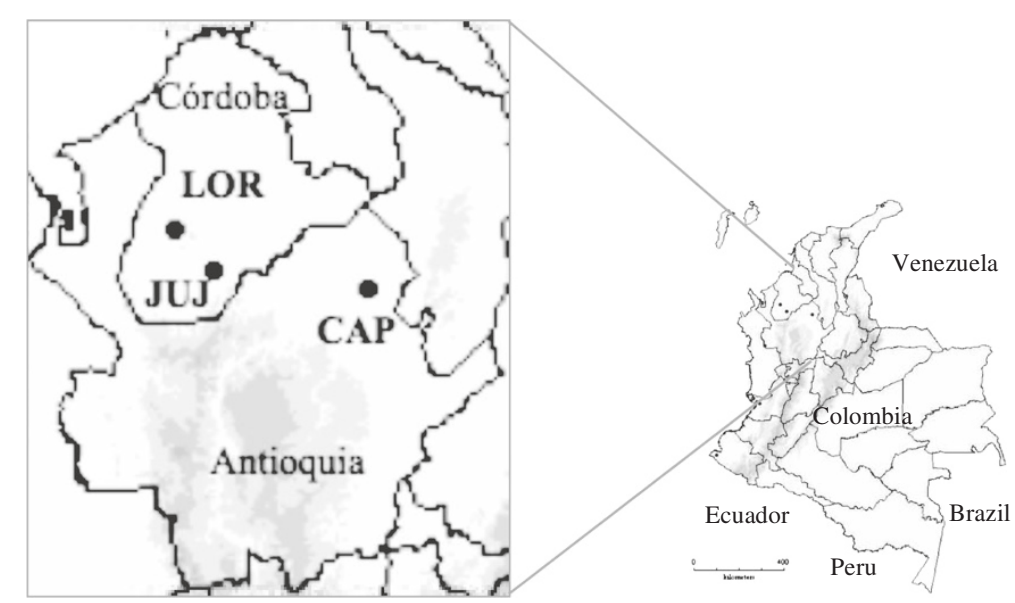

Figure 1 Collection sites. UCS region. El Loro-LOR and Juan Jose-JUJ, Córdoba Department and La Capilla-CAP, Antioquia Department.

number of mosquitoes analyzed by species, locality and region. IR values were calculated in two ways: (1) by collection period and (2) for the total number of days sampled. Confidence intervals (CI, 95\%) were calculated under the assumption of a binomial distribution using the EPIDAT program, version 3.1 (OPS/OMS 2006). For each site, the summed hourly data of four collections was used to calculate the human biting rate (HBR) as the total number of anophelines captured in each collection divided by the total number of collection days and the average number of collectors $[23,51]$. To detect variation resulting from differences in mosquito abundances and infection, the annual entomological inoculation rate (EIR) or the number of infective mosquito bites per year per locality was calculated. The annual EIR was obtained by multiplying the average HBR by the number of infected specimens during the four collections per site by 365 days $(E I R=H B R \times I R \times 365)$.

\section{Rainfall data}

Monthly rainfall data from pluviometric stations situated in proximity to the localities were obtained from the Instituto Colombiano de Hidrología, Meteorología y Estudios Ambientales (IDEAM). Spearman's correlation was performed to estimate the relationship between rainfall and mosquito abundance using pluviometric data of the previous month to a collection. The analysis was performed using the SPSS Program version 18 (SPSS Inc., Chicago, IL).

\section{Results}

\section{Anopheline abundance, distribution and seasonal variation}

A total of 5,316 anopheline mosquitoes corresponding to seven species were collected during $489 \mathrm{~h}$ of sampling (Table 1). CAP and JUJ were the sites showing the highest anopheline diversity with six species each, while in LOR only three species were detected (Table 1). The specimens An. nuneztovari were confirmed as such by PCR-RFLP-ITS2. In a COI network, grouped with sequences of the subclade IIC of Scarpassa \& Conn [33], designated as An. nuneztovari s.s. Anopheles nuneztovari and $A n$. darlingi were the most abundant species $(69.5 \%$ and $22.2 \%$, respectively) and were present in all three localities. The remaining species found in lower abundances included An. pseudopunctipennis (4.5\%), An. albitarsis s.l. (2\%), An. triannulatus lineage Northwest (NW) [41] (1.8\%), An. punctimacula and Anopheles argyritarsis Robineau-Desvoidy (each at $\leq 1 \%$ ). Given that An. punctimacula belongs to the Punctimacula Group, which is characterized by a high degree of isomorphism among its species [52-54] these specimens were confirmed using the barcode strategy. The total number of anophelines for each of the species collected did not show a normal distribution (KolmogorovSmirnov $Z=7.2, p<0.001)$. The number of collected mosquitoes per night by species varied markedly. For example, specimens of An. nuneztovari in LOR ranged from 1 to 55 per night $($ Mean $=19.6, \mathrm{SD} \pm 16.7), 4$ to 353 per night (Mean $=83.5, \mathrm{SD} \pm 118.3)$ in JUJ and 11 to 120 per night (Mean $=39.1, \mathrm{SD} \pm 24$ ) in CAP. Similarly, specimens of $A n$. darlingi ranged from 0 to 5 per night (Mean $=1 \mathrm{SD} \pm 1.4$ ) in JUJ and 10 to 194 per night (Mean $=46.7, \mathrm{SD} \pm 40.6)$ in CAP.

Anopheles nuneztovari in CAP was the most abundant species in the second and third collections (April-May and August 2009), accounting for $51.7 \%$ and $56.5 \%$ of total collections, respectively (Table 1). However in this locality, the peak abundance for this species was observed in the April-May 2009 collection, which coincides with the beginning of the rainy season (Figure 2A). In LOR and JUJ, An. nuneztovari predominated in all sites and collections, except in the third collection in JUJ (February 2010), a period of low rainfall when $A n$. 
Table 1 Data on abundance HBR, IR and EIR for the anopheline species collected

\begin{tabular}{|c|c|c|c|c|c|c|}
\hline $\begin{array}{l}\text { Department/Municipality/ } \\
\text { Locality }\end{array}$ & $\begin{array}{l}\text { Year Month } \\
\text { (Number of days) }\end{array}$ & Species & N (\%) & HBR & IR\% (CI) & $\begin{array}{c}\text { Annual } \\
\text { EIR }\end{array}$ \\
\hline \multirow{18}{*}{$\begin{array}{l}\text { Antioquia } \\
\text { El Bagre } \\
\text { La Capilla-CAP } \\
07^{\circ} 35^{\prime} N^{\circ} 49^{\prime} \mathrm{W}\end{array}$} & \multirow[t]{5}{*}{2009 January (6) } & An. darlingi & $358(63.9)$ & 14.1 & \multirow{4}{*}{$\begin{array}{c}\text { An. darlingi } \\
0.087 \text { PV VK210 } \\
(0.002-0.485)\end{array}$} & \multirow[t]{4}{*}{3.7} \\
\hline & & An. nuneztovari & $155(27.7)$ & 6.1 & & \\
\hline & & An. albitarsis s.l. & $33(5.9)$ & 1.4 & & \\
\hline & & An. triannulatus & $8(1.4)$ & 0.3 & & \\
\hline & & An. punctimacula & $6(1.1)$ & 0,3 & \multirow{4}{*}{$\begin{array}{c}\text { An. nuneztovari s.s. } \\
-0.101 \text { PV VK247 } \\
-\quad(0.003-0.559)\end{array}$} & \multirow[t]{4}{*}{3.5} \\
\hline & \multirow[t]{5}{*}{2009 April (2), May (4) } & An. nuneztovari & $452(51.7)$ & 16.7 & & \\
\hline & & An. darlingi & 366 (41.9) & 14.5 & & \\
\hline & & An. albitarsis s.l. & $41(4.7)$ & 1.7 & & \\
\hline & & An. triannulatus & $13(1.5)$ & 0.5 & \multirow{10}{*}{$\begin{array}{c}\text { An. triannulatus } \\
-1.515 \text { PV VK247 }{ }^{a} \\
-\quad(0.038-8.155)\end{array}$} & 4.8 \\
\hline & & An. pseudopunctipennis & $2(0.2)$ & 0.08 & & \\
\hline & \multirow[t]{4}{*}{2009 August (6) } & An. nuneztovari & $213(56.5)$ & 8.04 & & \\
\hline & & An. darlingi & $94(24.9)$ & 3.6 & & \\
\hline & & An. triannulatus & $49(13)$ & 2 & & \\
\hline & & An. albitarsis s.l. & $21(5.6)$ & 0.9 & & \\
\hline & \multirow[t]{4}{*}{2009 December (5) } & An. darlingi & $329(62.5)$ & 15.1 & & \\
\hline & & An. nuneztovari & $175(33.3)$ & 7.9 & & \\
\hline & & An. triannulatus & $12(2.3)$ & 0.6 & & \\
\hline & & An. albitarsis s.l. & $10(1.9)$ & 0.5 & & \\
\hline \multirow{9}{*}{$\begin{array}{l}\text { Córdoba } \\
\text { Tierralta } \\
\text { El Loro-LOR } \\
08^{\circ} 01^{\prime} \mathrm{N} 6^{\circ} 07^{\prime} \mathrm{W}\end{array}$} & \multirow[t]{3}{*}{2008 November (6) } & An. nuneztovari & 281 (98.9) & 6.9 & & \\
\hline & & An. triannulatus & $2(0.7)$ & 0.1 & & \\
\hline & & An. darlingi & $1(0.4)$ & 0.03 & & \\
\hline & \multirow[t]{3}{*}{2009 March (6) } & An. nuneztovari & $43(86)$ & 1.3 & & \\
\hline & & An. darlingi & $4(8)$ & 0.1 & & \\
\hline & & An. triannulatus & $3(6)$ & 0.1 & & \\
\hline & \multirow[t]{2}{*}{2009 June (6) } & An. nuneztovari & $166(99.4)$ & 5.3 & & \\
\hline & & An. triannulatus & $1(0.6)$ & 0.04 & & \\
\hline & 2009 September (6) & An. nuneztovari & $64(100)$ & 2.6 & & \\
\hline \multirow{12}{*}{$\begin{array}{l}\text { Córdoba } \\
\text { Puerto Libertador } \\
\text { Juan Jose-JUJ } \\
07^{\circ} 43^{\prime} \mathrm{N} 75^{\circ} 51^{\prime} \mathrm{W}\end{array}$} & \multirow[t]{2}{*}{2009 July (1), Aug (5) } & An. nuneztovari & $1,746(99.3)$ & 69 & & \\
\hline & & An. darlingi & $13(0.7)$ & 0.5 & & \\
\hline & \multirow[t]{2}{*}{2009 November (6) } & An. nuneztovari & $115(99.1)$ & 4.4 & \multirow{10}{*}{$\begin{array}{l}\text { An. nuneztovari } \\
0.047 \text { PV VK247 }{ }^{b} \\
(0.001-0.260)\end{array}$} & \multirow[t]{10}{*}{3.6} \\
\hline & & An. darlingi & $1(0.9)$ & 0.04 & & \\
\hline & \multirow[t]{4}{*}{2010 February (6) } & An. pseudopunctipennis & $236(62.6)$ & 9.6 & & \\
\hline & & An. nuneztovari & $130(34.5)$ & 4.6 & & \\
\hline & & An. darlingi & $10(2.6)$ & 0.38 & & \\
\hline & & An. punctimacula & $1(0.3)$ & 0.04 & & \\
\hline & \multirow[t]{4}{*}{2010 June (6) } & An. nuneztovari & $152(93.8)$ & 5.2 & & \\
\hline & & An. triannulatus & $6(3.7)$ & 0.3 & & \\
\hline & & An. darlingi & $3(1.9)$ & 0.08 & & \\
\hline & & An. argyritarsis & $1(0.6)$ & 0.04 & & \\
\hline
\end{tabular}

$N$ : Total number of anophelines collected by period. HBR: human biting rate per species (Average of mosquito bites/person/night calculated for each site and collection). IR: Infection rate (No. of positive/no. of total analyzed) $\times 100$, adetermined by a positive result on the first ELISA carried out with mosquito pools and by nested PCR of individual abdomens of positive pools, ${ }^{b}$ determined by the first and second positive ELISAs and by a nested PCR. Cl: IR confidence interval. Pv: Plasmodium vivax, Pf: Plasmodium falciparum. ElR: Entomological inoculation rate or the number of potential infective mosquito bites per species per year. Boldfaced: collection period and name of the species with infected mosquitoes. Anopheles triannulatus specimens correspond to lineage Northwest [41]. 
pseudopunctipennis predominated (62.6\%). In JUJ the number of the An. nuneztovari was relatively stable for the duration of our collections except for the first collection (July-August 2009) (Table 1), which likely represents an increase related to decreased rainfall (Figure 2A). In LOR, An. nuneztovari predominated and, in most collections, accounted for a relative abundance close to $99 \%$ and was the only species collected in the fourth sampling (September 2009) (Table 1). The peak abundance for this species in LOR was in November 2008, a period of decreased rainfall. A second peak was observed during the rainy period in June 2009 (Figure 2A).

Anopheles darlingi was present in all localities but predominated in CAP with $49.1 \%$ of the total anophelines collected. In this site, $A n$. darlingi was more abundant during the first (63.9\%) and fourth (62.5\%) collections, corresponding with the onset (January 2009) and decline of the rains (December 2009), respectively. Anopheles darlingi was less abundant than $A n$. nuneztovari in the other two collections (Table 1) and was least abundant in the third collection (August 2009), during the rainiest period (Figure 2B). In LOR, $A n$. darlingi was present in low abundance in the first and second collections (November 2008 and March 2009), with $0.4 \%$ and $8 \%$, respectively. In JUJ, $A n$. darlingi was present in low abundances in all collections (0.7-2.6\%) (Table 1). In both LOR and JUJ, increased An. darlingi densities were temporally associated with the transition periods at the beginning or end of the rains (Figure 2B).

Anopheles triannulatus was present in low abundance in all localities. In CAP, peak abundance of $A n$. triannulatus occurred in the third collection (August 2009), which coincided with the peak of the rainy season (13\%) (Figure 2C). In LOR, peak abundance of $A n$. triannulatus (6\%) occurred at the beginning of the rainy season (March 2009), and it was not detected in the last collection (September 2009) (Table 1 and Figure 2C). In JUJ, An. triannulatus was only collected in the fourth sampling (June 2010), corresponding to a rainy period, with a relative abundance of $3.7 \%$ (Table 1 and Figure 2C).

Anopheles albitarsis s.l. Galvão \& Damasceno was only collected in CAP, present in all collections, with densities ranging from $1.9 \%$ to $5.9 \%$ (Table 1 ), with peak abundance at the onset of the rainy season (not shown). Anopheles pseudopunctipennis and An. punctimacula, considered secondary vectors in Colombia, were detected in CAP and JUJ, in only one collection and in low frequencies (Table 1), during periods of low rain intensity or

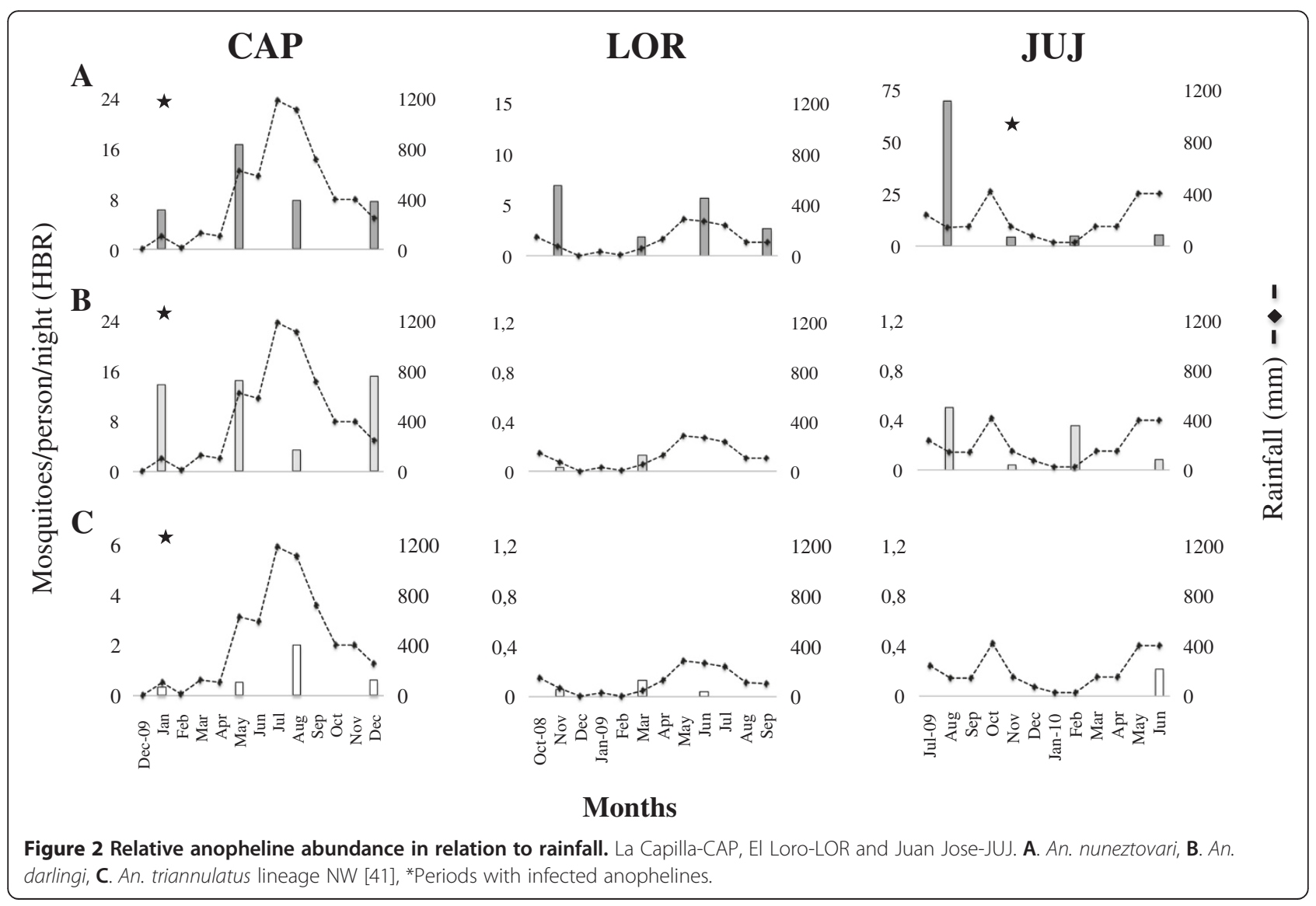


at the beginning of the rain (not shown). Remarkably, in JUJ, An. pseudopunctipennis predominated (62.6\%) in the only collection period in which this species was detected, which corresponded to a dry period. Only one $A n$. argyritarsis specimen $(0.6 \%)$ was collected in JUJ during a rainy period (June 2010) (Table 1). There was not a significant $(p>0.05)$ correlation between mosquito abundance and rain for any site or species.

\section{Biting activity}

Among the species collected that have been identified as potential human plasmodium vectors, none exhibited an exclusive tendency for biting indoors or outdoors and their activity varied in the different localities (Figure 3). In general, 54\% An. nuneztovari specimens were collected indoors and $46.6 \%$ outdoors, values which were not significantly different $(t=1.18, p>0.05, \mathrm{n}=71)$. However, An. nuneztovari exhibited a significant difference in indoor/outdoor biting tendency among localities, with endophagic preferences in LOR and CAP $(t=2.27$, $p<0.05, \mathrm{n}=24$ and $t=2.58, p<0.05, \mathrm{n}=23$, respectively) (Figure $3 \mathrm{~A}$ and $3 \mathrm{~B}$ ). Anopheles darlingi did not show marked indoor/outdoor biting preference, with $50.9 \%$ of specimens collected outdoors and $49.1 \%$ indoors in CAP (Figure 3D). Because of the low number of An. darlingi collected in LOR and JUJ it was not possible to analyze biting preferences for this species in these localities.

Mosquito biting activity was determined for the most abundant species from 18:00-24:00 $\mathrm{h}$ and during one night from 18:00-6:00 $\mathrm{h}$, and expressed as the mean proportion of mosquitoes collected per hour per species (Figure 3). In general, An. nuneztovari exhibited biting activity throughout the night. However, biting peaks varied slightly at collection sites. For example, the highest biting activity was between 20:00-22:00 h, indoors in CAP, and outdoors in JUJ, and between 21:00-22:00 h, indoors in LOR (Figure 3A, 3B and 3C). Biting peaks during the overnight collection were low and occurred at 02:00-03:00 $\mathrm{h}$ in LOR, 24:00-01:00 $\mathrm{h}$ in JUJ and 01:00-02:00 h CAP (data not shown). The highest biting activity for $A n$. darlingi in CAP was outdoors between 22:00-23:00 h (Figure 3D), with an overnight peak registered between 24:00 and 02:00 h (data not shown).

\section{Human biting rate}

Among all species, the primary vectors $A n$. nuneztovari and An. darlingi showed the highest HBRs (Table 1). The highest HBR was registered for An. nuneztovari in JUJ during the July-August 2009 collection (69 bites per night), while An. darlingi showed higher HBRs in CAP in three of the four collections, ranging from 14.1 to 15.1 bites per

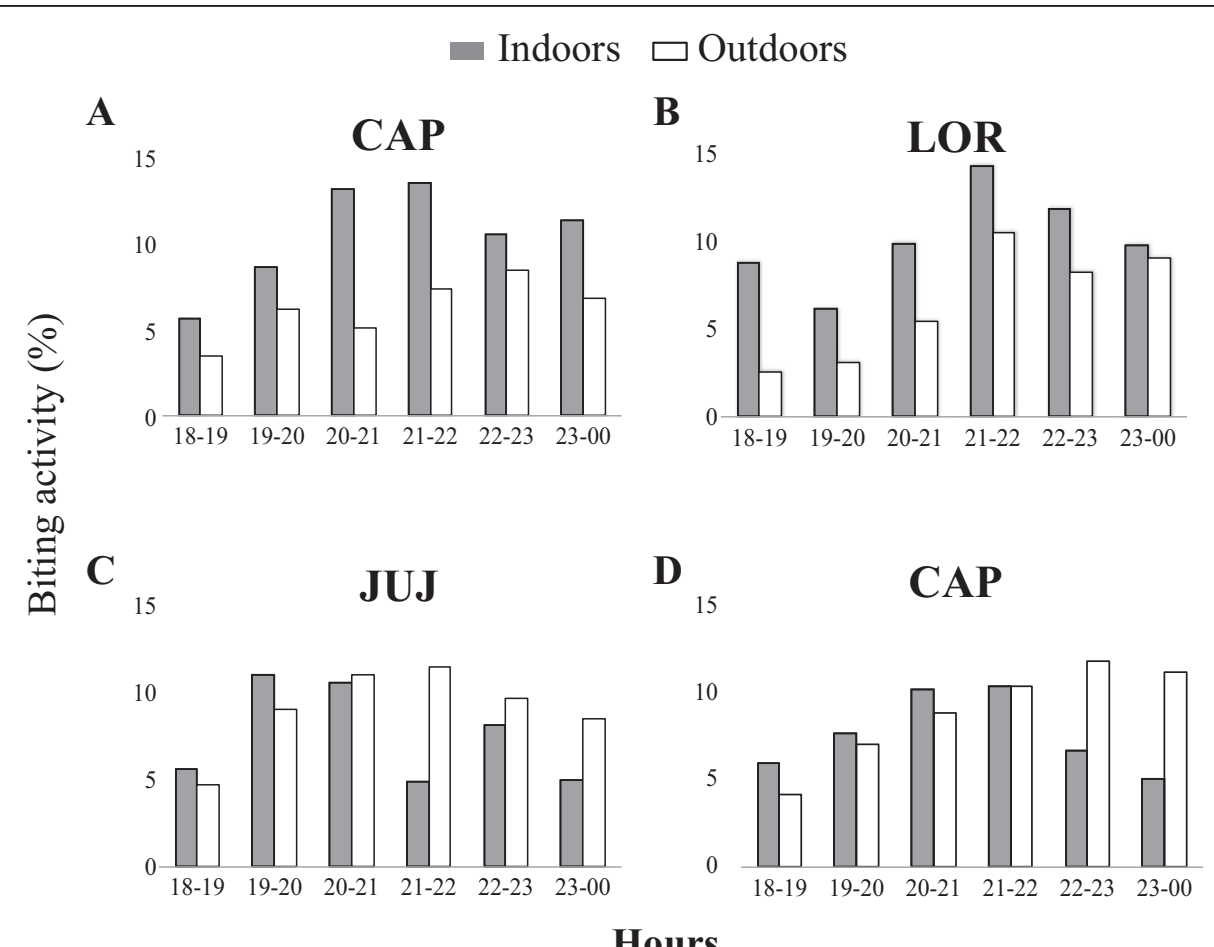

Figure 3 Mosquito biting activity by hours. A. An. nuneztovari in La Capilla-CAP, B. An. nuneztovari in El Loro-LOR, C. An. nuneztovari in Juan Jose-JUJ, D. An. darlingi in La Capilla-CAP. 
night (Table 1). Surprisingly, An. pseudopunctipennis, generally a low abundance species, exhibited a HBR of 9.6 bites per night in the February 2010 collection in JUJ, which was higher than that of An. nuneztovari (4.6 bites per night), in the same period (Table 1).

\section{Infection rate and entomological inoculation rate}

A total of 5,299 were processed for infection analysis, four infected specimens were detected in two of the three localities (Table 1). In CAP, An. nuneztovari and An. triannulatus were infected with $P$. vivax VK247 (IR of $0.101 \%$ and $1.515 \%$, respectively) and one specimen of $A n$. darlingi was infected with $P$. vivax VK210 (IR of $0.087 \%$ ). In JUJ, one An. nuneztovari specimen was infected with $P$. vivax VK247 (IR of 0.047\%) (Table 1). When the IR was calculated by collection period, $A n$. triannulatus had the highest IR (12.5\%), which was influenced by its low abundance. In general, however, mean annual EIRs were low, with four infective bites per year (Table 1). The HBRs influenced the EIRs, except for An. triannulatus (Table 1). In general, cumulative EIR values indicate higher malaria intensity in CAP (12 infective bites per year) than in JUJ (3.6 infective bites per year).

\section{Discussion}

In the UCS region, 24 anopheline species have been previously registered [7]. Historically, the reported malaria vectors included $A n$. albimanus, An. darlingi and $A n$. nuneztovari $[8,9]$. In the present study, An. nuneztovari was the predominant species in two of the three USC localities evaluated (JUJ and LOR), while in CAP, $A n$. darlingi predominated, followed by An. nuneztovari. Studies conducted in this region during the last decade reported the presence of these two main Colombian vectors $[8,40]$, but those studies did not included periodic samplings that can reveal fluctuations of these main vectors or other species of local importance.

In this study, An. darlingi showed higher abundances during the transition periods (at the beginning or end of the rains), consistent with most reports for this species in localities of other Latin-American countries such as Venezuela, Brazil and Belize [55-57]. Occasionally, however, high densities have been reported in the dry season in some regions of Brazil [23,36]. Possible reasons for higher densities during the transition periods have been related to human activities that may provide larval habitats that persist in the dry season or transitional period [58]. In CAP, where An. darlingi predominated, the main economic activities are alluvial mining, followed by livestock and small scale rice production, which provide larval habitats for $A n$. darlingi that can wash out during prolonged rain periods [56-60]. Low densities of $A n$. darlingi in JUJ and LOR may be related to human activities and temporary larval habitats associated with timber extraction, livestock and crop production, which are clearly distinct from the natural rainforest larval habitats typical for $A n$. darlingi such as lagoons, forested river margins and streams covered with vegetation [55,61-63].

The dominance of $A n$. nuneztovari in Cordoba may be related to environmental disturbance. This species has been characterized by its adaptability and ability to colonize artificial larval habitats in impacted areas $[37,64]$. In CAP, open sky mining and in LOR and JUJ, artificial ponds for aquaculture and livestock production with the flooding of pastures during rainy periods, can provide the appropriate larval habitats for An. nuneztovari [56]. Association of high densities of An. nuneztovari with rainy periods has also been reported for other places of Brazil [56] and Venezuela [65].

The low densities found for An. triannulatus may be influenced by the collection method since both zoophilic [39] and anthropophilic activity [8] have been reported for this species in the northwest Colombia. Anopheles triannulatus was collected at the beginning or during rainy periods when larval habitats associated with lakes and river margins [66], ditches and open sky mining $[8,67,68]$, would be readily available. Previous studies in Venezuela and Brazil reported higher An. triannulatus densities during and at the end of the rains $[56,59,65]$. Given that $A n$. triannulatus comprises a species complex, that in Colombia there is no evidence of the presence of the different species and that two lineages were detected with the NW lineage occurring in the UCS region [41], we suggest that the taxonomic status of these specimens should be clarified to draw accurate inferences about the ecological and behavioral characteristics of this taxon.

Anopheles albitarsis s.l. was only collected in CAP and showed its highest peak at the onset of the rainy period. Some species of the Albitarsis Complex, such as An. marajoara, have been associated with disturbed environments [20,69] such as mining excavations, with higher peaks in the rainy season [55]. However, a better definition of the Albitarsis Complex species present in Colombia is required for proper interpretation of our findings. In contrast to An. albitarsis s.l., An. punctimacula and An. pseudopunctipennis were collected during dry or very low rain periods. This is consistent with previous reports indicating presence of these two species mostly in the dry period [70-72]. Low densities of An. punctimacula in NW Colombia [73] were related to its zoophilic tendency $[72,74]$; therefore, livestock production in CAP and JUJ may provide an additional feeding resource for these species and human landing catches would underestimate their actual abundance.

In this survey, anopheline biting activity varied. Similar to previous reports outdoors $[8,40]$, the highest biting 
peaks for An. nuneztovari in these localities were in the range of 20:00-22:00 h, with activity in both, indoors and outdoors. In CAP, An. darlingi predominated, showing biting activity through the night with the highest biting peak outdoors between 21:00-22:00 h. The main biting peaks for these two vectors took place in hours where the people are in their houses involved in leisure activities. Therefore, vector control strategies such as the use of repellents and the applications of residual insecticides may be directed to reduce human-vector contact.

Total HBRs for An. nuneztovari and An. darlingi differed by locality. HBRs for An. nuneztovari were higher than those previously reported for this species in this region [8], or in the east $[69,75]$ and Pacific region of Colombia [69,75]. In Brazil, low HBR values for $A n$. nuneztovari have also been reported [23], but also high or higher than the ones found in this study have been reported (30.3 to 123.7 bites per night) [35]. Because $A n$. nuneztovari is a complex of at least two species, one in Colombia and Venezuela and the other in Brazil [31,33], ecological and behavioral differences may influence HBR. For An. darlingi, HBRs varied significantly among localities and were similar or lower than those previously recorded in other UCS localities [8], and in eastern Colombia [69]. As in the present study, low HBRs have also been reported in the Brazilian Amazon where $A n$. darlingi is an important vector [21,23], however, in this region the highest HBRs have also been registered (53.8 to 837.7 bites per night) [35].

Infected mosquitoes were collected during periods of low rainfall, in agreement with previous work in Colombia that related higher malaria transmission to periods of low rain [76]. The low IRs found for $A n$. nuneztovari and An. darlingi are consistent with those previously found in other UCS sites $[8,39,77]$, indicating that IRs remain relative stable in these localities. Until now, however, An. triannulatus has not been incriminated as a malaria vector in Colombia. In this study one specimen from CAP was found infected in the first ELISA and the nested PCR. Although the IR was higher than for the two main malaria vectors, this value was strongly influenced by the low number of specimens collected and analyzed. Our findings should be interpreted in the context of false positives that have been reported mostly for ELISA [78,79], particularly for anophelines with zoophilic preferences [78]. Most importantly, however, a positive PCR indicates presence of the parasite but not necessarily that the mosquito is infective. We also note that $A n$. punctimacula and $A n$. pseudopunctipennis, species that have been historically considered of local importance [7,9,39], were generally collected in low numbers and were not infected, so their epidemiological relevance in our study sites could not be confirmed.
The IRs, HBRs and EIRs values for An. nuneztovari and $A n$. darlingi provide additional evidence of the importance of these species in malaria transmission in the UCS sites. EIR, which reflects transmission intensity [80], was influenced by the HBR for An. darlingi and An. nuneztovari and by the high IR for An. triannulatus. The annual EIR for An. nuneztovari in CAP and JUJ is considered high for a non-Amazon region where EIRs as high as 141.25 infective bites per year have been reported in the Amazonian locality of Saõ João [35]. At these UCS sites, the EIRs indicate that a person would receive approximately one infected bite every three months. The annual EIR for An. darlingi in CAP is similar to the EIR reported for $A n$. darlingi in mining areas of southern Venezuela [81]. However, higher EIRs have been reported in forested areas of other Latin American countries where An. darlingi occurs at high densities and is a main vector, for example in French Guyana (14.4 to 27.4 infective bites per year) [82], in Rondõnia State (10 infective bites per year) [83], and in Amapá State localities, Brazilian Amazon (up to 1 infective bite per day) [35]. The low EIR registered for An. triannulatus is consistent with values previously reported that suggested that this species in high density had importance in local transmission [35]. Although An. triannulatus was found to be infected with $P$. vivax, its importance as a malaria vector in Colombia needs to be clarified.

\section{Conclusions}

In the present study, regular field trips over a nearly two year period were conducted in highly endemic UCS to refine knowledge of the temporal and geographic distributions for species considered potential malaria vectors. In general, the results demonstrated that $A n$. nuneztovari and $A n$. darlingi continue to be the main malaria vectors in UCS localities. Infected specimens were detected in periods when the HBRs for these species were low, indicating that they maintain malaria transmission even in low densities. Furthermore, information on the EIR, an indicator of transmission intensity, may be used to maximize the resources used for control efforts that according to the results should be applied specially in transition and low rain periods. The EIR values are also useful in future studies directed to evaluate the efficacy of the control measure in this area. Additional studies are recommended to investigate the role of $A n$. triannulatus as a local vector in Colombia.

\section{Competing interests}

The authors declare that they have no competing interests.

\section{Authors' contributions}

NND carried out field and laboratory work, data analysis and interpretation, and manuscript draft. DR performed mosquito infection experiments and data analysis. GRU and SL participated in the design of the study, data analysis and critical revision of the final manuscript. MMC conceived and 
designed the study, coordinated the research group, participated in data analyses and performed critical revisions of manuscript drafts. All authors read and approved the final manuscript.

\section{Acknowledgements}

This work was funded by the National Institutes of Health NIH-USA, Grant No. R03-Al076710 and Estrategia para la Sostenibilidad de Grupos 2011-2012 Universidad de Antioquia, No. E01624, to MMC.

We are grateful to S. Berrocal, Director of the Hospital Nuestra Señora del Carmen, El Bagre Antioquia, and Personnel at the Dirección Local de Salud de Tierralta, Córdoba for their logistic support during this work. M. Altamiranda, J.C. Marin, G.F. Gómez and A. Yate for mosquito collection. N. Alvárez and L.M. Jaramillo for laboratory technical support.

\section{Author details}

'Grupo de Microbiología Molecular. Escuela de Microbiología, Universidad de Antioquia, Medellín, Colombia. ${ }^{2}$ Grupo de Entomología Médica. Facultad de Medicina, Universidad de Antioquia, Medellín, Colombia. ${ }^{3}$ Department of Medical Microbiology and Immunology, University of California, Davis, CL, USA.

Received: 19 February 2013 Accepted: 22 February 2013

Published: 7 March 2013

\section{References}

1. WHO- World Health Organization: World malaria report 2010. Genove: WHO; 2010.

2. OPS: Informe de la situación del paludismo en las Américas, 2008. Washington D.C: Pan American Health Organization; 2009.

3. INS- Instituto Nacional de Salud. Boletín epidemiológico Semanal: Estadísticas del sistema de vigilancia en salud pública- SIVIGILA, casos totales en la semana epidemiológica 52 y acumulados del año, subdirección de vigilancia y control en salud pública. 2010. http://www.ins.gov.co/lineas-deaccion/Subdireccion-Vigilancia/sivigila/Estadsticas\%20SIVIGILA/SEMANA\% 2052\%20DE\%202010.pdf

4. INS- Instituto Nacional de Salud: Boletín epidemiológico semanal. Estadísticas del sistema de vigilancia en salud pública- SIVIGILA, casos totales en la semana epidemiológica 52 y acumulados del año, subdirección de vigilancia y control en salud pública. 2011. http://www.ins.gov.co/lineas-de-accion/SubdireccionVigilancia/sivigila/Paginas/vigilancia-rutinaria.aspx.

5. Korenromp E: Malaria incidence estimates at country level for the year 2004. Geneva: Proposed estimates and draft report. WHO; 2005.

6. Rodríguez JC, Uribe GÁ, Araújo RM, Narváez PC, Valencia SH: Epidemiology and control of malaria in Colombia. Mem Inst Oswaldo Cruz 2011, 106:114-122.

7. González R, Carrejo N: Introducción al estudio taxonómico de Anopheles de Colombia Claves y notas de distribución. 2nd edition. Cali: Universidad del Valle; 2009.

8. Gutiérrez LA, González JJ, Gómez GF, Castro MI, Rosero DA, Luckhart S, Conn JE, Correa MM: Species composition and natural infectivity of anthropophilic Anopheles (Diptera: Culicidae) in the States of Córdoba and Antioquia, northwestern Colombia. Mem Inst Oswaldo Cruz 2009, 104:1117-1124

9. Olano V, Brochero H, Sáenz R, Quiñones M, Molina J: Mapas preliminares de la distribución de especies de Anopheles vectores de malaria en Colombia. Biomedica 2001, 21:402-408.

10. Quiñones ML, Ruiz F, Calle DA, Harbach RE, Erazo HF, Linton Y-M: Incrimination of Anopheles (Nyssorhynchus) rangeli and An. (Nys.) oswaldoi as natural vectors of Plasmodium vivax in Southern Colombia. Mem Inst Oswaldo Cruz 2006, 101:617-623.

11. Krzywinski J, Li C, Morris M, Conn JE, Lima JB, Povoa MM, Wilkerson RC: Analysis of the evolutionary forces shaping mitochondrial genomes of a neotropical malaria vector complex. Mol Phylogenet Evol 2011, 58:469-477.

12. Brochero HHL, Li C, Wilkerson RC: A newly recognized species in the Anopheles (Nyssorhynchus) albitarsis complex (Diptera: Culicidae) from Puerto Carreño, Colombia. Am J Trop Med Hyg 2007, 76:1113-1117.

13. Lehr MA, Kilpatrick CW, Wilkerson RC, Conn JE: Cryptic species in the Anopheles (Nyssorhynchus) albitarsis (Diptera: Culicidae) complex: incongruence between random amplified polymorphic DNA-polymerase chain reaction identification and analysis of mitochondrial DNA COI gene sequences. Ann Entomol Soc Am 2005, 98:908-917.
14. Motoki MT, Wilkerson RC, Sallum MAM: The Anopheles albitarsis complex with the recognition of Anopheles oryzalimnetes Wilkerson \& Motoki, $\mathrm{n}$. sp. \& Anopheles janconnae Wilkerson and Sallum, n. sp. (Diptera: Culicidae). Mem Inst Oswaldo Cruz 2009, 104:823-850.

15. Wilkerson RC, Foster PG, Li C, Sallum MAM: Molecular phylogeny of neotropical Anopheles (Nyssorhynchus) albitarsis species complex (Diptera: Culicidae). Ann Entomol Soc Am 2005, 98:918-925.

16. Ruiz-Lopez F, Wilkerson RC, Conn JE, McKeon SN, Levin DM, Quiñones ML, Póvoa MM, Linton Y-M: DNA barcoding reveals both known and novel taxa in the Albitarsis group (Anopheles: Nyssorhynchus) of neotropical malaria vectors. Parasit Vectors 2012, 5:44.

17. Branquinho MS, Lagos CB, Rocha RM, Natal D, Barata JM, Cochrane AH, Nardin E, Nussenzweig RS, Kloetzel JK: Anophelines in the State of Acre, Brazil, infected with Plasmodium falciparum, $P$. vivax, the variant $P$. vivax VK247 and P. malariae. Trans Royal Soc Trop Med Hyg 1993, 87:391-394.

18. Klein TA, Lima JB, Tada MS: Comparative susceptibility of anopheline mosquitoes to Plasmodium falciparum in Rondonia, Brazil. Am J Trop Med Hyg 1991, 44:598-603.

19. Klein TA, Lima JB, Tada MS, Miller R: Comparative susceptibility of anopheline mosquitoes in Rondonia, Brazil to infection by Plasmodium vivax. Am J Trop Med Hyg 1991, 45:463-470.

20. Conn JE, Wilkerson RC, Segura MNO, De Souza RTL, Schlichting CD, Wirtz RA, Póvoa MM: Emergence of a new neotropical malaria vector facilitated by human migration and changes in land use. Am J Trop Med Hyg 2002, 66:18-22.

21. Póvoa MM, De Souza RTL, Lacerda RN, da L, Rosa ES, Galiza D, De Souza JR Wirtz RA, Schlichting CD, Conn JE: The importance of Anopheles albitarsis $\mathrm{E}$ and An. darlingi in human malaria transmission in Boa Vista, State of Roraima, Brazil. Mem Inst Oswaldo Cruz 2006, 101:163-168.

22. Gutiérrez LA, Orrego LM, Gómez GF, López A, Luckhart S, Conn JE, Correa MM: A new mtDNA COI gene lineage closely related to Anopheles janconnae of the Albitarsis Complex in the Caribbean region of Colombia. Mem Inst Oswaldo Cruz 2010, 105:1019-1025.

23. Da Silva-Vasconcelos A, Kató MYN, Mourão EN, De Souza RTL, Lacerda RN, da L, Sibajev A, Tsouris P, Póvoa MM, Momen H, Rosa-Freitas MG: Biting indices, host-seeking activity and natural infection rates of anopheline species in Boa Vista, Roraima, Brazil from 1996 to 1998. Mem Inst Oswaldo Cruz 2002, 97:151-161.

24. Silva-Do-Nascimento TF, Wilkerson RC, Lourenço-De-oliveira R, Monteiro FA: Molecular confirmation of the specific status of Anopheles halophylus (Diptera: Culicidae) and evidence of a new cryptic species within An. triannulatus in central Brazil. J Med Entomol 2006, 43:455-459.

25. Cienfuegos AV, Rosero DA, Naranjo N, Luckhart S, Conn JE, Correa MM: Evaluation of a PCR-RFLP-ITS2 assay for discrimination of Anopheles species in northern and western Colombia. Acta Trop 2011, 118:128-135.

26. Fajardo Ramos M, González Obando R, Fidel Suárez M, López D, Wilkerson R, Sallum MAM: Morphological analysis of three populations of Anopheles (Nyssorhynchus) nuneztovari Gabaldón (Diptera: Culicidae) from Colombia. Mem Inst Oswaldo Cruz 2008, 103:85-92.

27. Cienfuegos A, Gómez G, Córdoba L, Luckhart S, Conn J, Correa M: Diseño y evaluación de metodologías basadas en PCR-RFLP de ITS2 para la identificación molecular de mosquitos Anopheles spp. (Diptera: Culicidae) de la Costa Pacífica de Colombia. Rev Biomed (Mex) 2008, 19:35-44.

28. Gómez G, Cienfuegos A, Gutiérrez L, Conn J, Correa M: Análisis morfológico y molecular evidencia problemas al identificar Anopheles nuneztovari (Diptera: Culicidae) por claves dicotómicas. Rev Col Ent 2010, 36:68-75.

29. Calado DC, Foster PG, Bergo ES, dos Santos CLS, Galardo AKR, Sallum MAM: Resurrection of Anopheles goeldii from synonymy with Anopheles nuneztovari (Diptera: Culicidae) and a new record for Anopheles dunhami in the Brazilian Amazon. Mem Inst Oswaldo Cruz 2008, 103:791-799.

30. Lounibos L, Conn JE: Malaria vector heterogeniety in South America. Am Entomol 2000, 46:238-249.

31. Mirabello L, Conn JE: Population analysis using the nuclear white gene detects Pliocene/Pleistocene lineage divergence within Anopheles nuneztovari in South America. Med Vet Entomol 2008, 22:109-119.

32. Kitzmiller JB, Kreutzer RD, Tallaferro E: Chromosomal differences in populations of Anopheles nuneztovari. Bull World Health Organ 1973, 48:435-445.

33. Scarpassa VM, Conn JE: Mitochondrial DNA detects a complex evolutionary history with Pleistocene Epoch divergence for the neotropical malaria vector Anopheles nuneztovari sensu lato. Am J Trop Med Hyg 2011, 85:857-867.

34. Fajardo P, Alzate A: Anopheles nuneztovari como vector de malaria en el Bajo Calima, Buenaventura, Colombia. Colombia Med 1987, 18:14-18. 
35. Galardo AKR, Arruda M, D'Almeida Couto AAR, Wirtz R, Lounibos LP, Zimmerman $\mathrm{RH}$ : Malaria vector incrimination in three rural riverine villages in the Brazilian Amazon. Am J Trop Med Hyg 2007, 76:461-469.

36. Póvoa M, Wirtz R, Lacerda R, Miles M, Warhurst D: Malaria vectors in the municipality of Serra do Navio, State of Amapá, Amazon region, Brazil. Mem Inst Oswaldo Cruz 2001, 96:179-184.

37. Tadei WP, Dutary Thatcher B: Malaria vectors in the Brazilian Amazon: Anopheles of the subgenus Nyssorhynchus. Rev Inst Med Trop Sao Paulo 2000, 42:87-94.

38. Aramburú-Guarda J, Ramal Asayag CWR: Malaria re-emergence in the Peruvian Amazon region. Emerg Infect Dis 1999, 5:209-215.

39. Gutiérrez LA, Naranjo N, Jaramillo LM, Muskus C, Luckhart S, Conn JE, Correa MM: Natural infectivity of Anopheles species from the Pacific and Atlantic regions of Colombia. Acta Trop 2008, 107:99-105.

40. Parra-Henao G, Alarcon Pineda EP: Observaciones sobre la bionomía de Anopheles spp. (Diptera: Culicidae) en el municipio Valencia, Departamento Córdoba, Colombia. Boletín de Malariología y Salud Ambiental 2008, 48:95-98.

41. Rosero DA, Jaramillo LM, Gutiérrez LA, Conn JE, Correa MM: Genetic diversity of Anopheles triannulatus s.l. (Diptera: Culicidae) from Northwestern and Southeastern Colombia. Am J Trop Med Hyg 2012, 87:910-920.

42. Gonzalez R, Carrejo N: Introducción al estudio taxonómico de Anopheles de Colombia claves y notas de distribución. Cali: Universidad del Valle; 2007.

43. Faran M, Linthicum L: Handbook of the Amazonian species of Anopheles (Nyssorhynchus) (Diptera: Culicidae). Mosa Syst 1981, 13:1-81

44. Zapata MA, Cienfuegos AV, Quirós Ol, Quiñones ML, Luckhart S, Correa MM: Discrimination of seven Anopheles species from San Pedro de Urabá, Antioquia, Colombia, by polymerase chain reaction-restriction fragment length polymorphism analysis of ITS2 sequences. Am J Trop Med Hyg 2007, 77:67-72.

45. Hebert PDN, Cywinska A, Ball SL, De Waard JR: Biological identifications through DNA barcodes. Proc R Soc Lond B 2003, 270:313-321.

46. Folmer O, Black M, Hoeh W, Lutz R, Vrijenhoek R: DNA primers for amplification of mitochondrial cytochrome c oxidase subunit I from diverse metazoan invertebrates. Mol Mar Biol Biotechnol 1994, 3:294-299.

47. Wirtz RA, Zavala F, Charoenvit Y, Campbell GH, Burkot TR, Schneider I, Esser KM, Beaudoin RL, Andre RG: Comparative testing of monoclonal antibodies against Plasmodium falciparum sporozoites for ELISA development. Bull World Health Organ 1987, 65:39-45.

48. Wirtz RA, Sattabongkot J, Hall T, Burkot TR, Rosenberg R: Development and evaluation of an enzyme-linked immunosorbent assay for Plasmodium vivax-VK247 sporozoites. J Med Entomol 1992, 29:854-857.

49. Singh B, Bobogare A, Cox-Singh J, Snounou G, Abdullah MS, Rahman HA: A genus- and species-specific nested polymerase chain reaction malaria detection assay for epidemiologic studies. Am J Trop Med Hyg 1999, 60:687-692.

50. Rosero D, Gutiérrez L, Cienfuegos A, Jaramillo L, Correa M: Optimización de un procedimiento de extracción de ADN para mosquitos anofelinos. Rev Col Ent 2010, 36:260-263.

51. Macdonald G: The epidemiology and control of malaria. London: Oxford; 1957.

52. Harbach RE: The classification of genus Anopheles (Diptera: Culicidae): a working hypothesis of phylogenetic relationships. Bull Entomol Res 2004 94:537-553.

53. Wilkerson R: Anopheles (Anopheles) calderoni n. sp., a malaria vector of the Arribalzagia series from Peru (Diptera: Culicidae). Mosq Syst 1991, 23:25-38.

54. Wilkerson R: Redescriptions of Anopheles punctimacula and An. malefactor. J Med Entomol 1990, 27:225-247.

55. Moreno JE, Rubio-Palis Y, Páez E, Pérez E, Sánchez V: Abundance, biting behaviour and parous rate of anopheline mosquito species in relation to malaria incidence in gold-mining areas of southern Venezuela. Med Vet Entomol 2007, 21:339-349.

56. Galardo AKR, Zimmerman RH, Lounibos LP, Young LJ, Galardo CD, Arruda M, D'Almeida Couto AAR: Seasonal abundance of anopheline mosquitoes and their association with rainfall and malaria along the Matapí river, Amapá, Brazil. Med Vet Entomol 2009, 23:335-349.

57. Achee NL, Grieco JP, Rejmankova E, Andre RG, Vanzie E, Polanco J, Briceno I, King R, Roberts DR: Biting patterns and seasonal densities of Anopheles mosquitoes in the Cayo District, Belize, Central America with emphasis on Anopheles darlingi. J Vect Ecol 2006, 31:45-57.
58. Hiwat H, Bretas G: Ecology of Anopheles darlingi root with respect to vector importance: a review. Parasit Vectors 2011, 4:177.

59. Souza-Santos R: Distribuição sazonal de vetores da malaria amazônica, Brasil seasonal distribution of malaria vectors in Machadinho d' oeste, Rondônia State, Amazon region, Brazil. Cad Saude Publica 2002, 18:1813-1818.

60. Hayes J, Charlwood J: Dinâmica estacional de uma populaçâo de Anopheles darlingi numa area endemica de malaria no Amazonas. Acta Amaz 1979, 9:79-86.

61. Linthicum K: A revision of the Argyritarsis section of the subgenus Nyssorhynchus of Anopheles (Diptera: Culicidae). Mosa Syst 1988, 20:98-271.

62. Rubio-Palis Y, Menare C, Quinto A, Magris M, Amarista M: Caracterización de criaderos de anofelinos (Diptera: Culicidae) vectores de malaria del Alto Orinoco, Amazonas, Venezuela. Entomotropica 2005, 20:29-38.

63. Vittor AY, Pan W, Gilman RH, Tielsch J, Glass G, Shields T, Sánchez-Lozano W, Pinedo W, Salas-Cobos E, Flores S, Patz JA: Linking deforestation to malaria in the Amazon: characterization of the breeding habitat of the principal malaria vector, Anopheles darlingi. Am J Trop Med Hyg 2009, 81:5-12.

64. Tadei WP, Thatcher BD, Santos JM, Scarpassa VM, Rodrigues IB, Rafael MS: Ecologic observations on anopheline vectors of malaria in the Brazilian Amazon. AmJTrop Med Hyg 1998, 59:325-335.

65. Rubio-Palis Y, Wirtz RA, Curtis CF: Malaria entomological inoculation rates in western Venezuela. Acta Trop 1992, 52:167-174.

66. Faran M: Mosquitos studies (Diptera, Culicidae) XXXIV. A revision of the Albimanus section of the subgenus Nyssorhynchus of Anopheles. Contrib Amer Ent Inst 1980, 15:1-215.

67. Lopez J, Lozovei A: Ecologia de mosquitos (Diptera: Culicidae) em criadouros naturais e artificiais de área rural do norte do estado do Paraná, Brasil. I. Coletas ao longo do leito do Ribeirão. Rev Saude Publ 1995, 29:183-191.

68. Silva A: Imaturos de mosquitos (Diptera, Culicidae) de áreas urbana e rural no norte do estado do Paraná, Brasil. Iheringia Ser Zool 2002, 92:31-36.

69. Brochero HL, Rey G, Buitrago LS, Olano VA: Biting activity and breeding sites of Anopheles species in the municipality Villavicencio, Meta, Colombia. J Am Mosa Control Assoc 2005, 21:182-186.

70. Manguin S, Roberts DR, Peyton EL, Rejmankova E, Pecor J: Characterization of Anopheles pseudopunctipennis larval habitats. J Am Mosa Control Assoc 1996, 12:619-626.

71. Lardeux F, Loayza P, Bouchité B, Chavez T: Host choice and human blood index of Anopheles pseudopunctipennis in a village of the Andean valleys of Bolivia. Malar J 2007, 6:8.

72. Ulloa A, Gonzalez-Cerón L, Rodríguez MH: Host selection and gonotrophic cycle length of Anopheles punctimaculain southern Mexico. J Am Mosq Control Assoc 2006, 22:648-653.

73. Elliot R: Studies on man - vector contact in some malarious areas in Colombia. Bull World Health Organ 1968, 38:239-253.

74. Elliott R: The influence of vector behavior on malaria transmission AmJTrop Med Hyg 1972, 21:755-763.

75. Olano V, Carrasquilla G, Méndez F: Transmisión de la malaria urbana en Buenaventura, Colombia: aspectos entomológicos. Pan Am J Public Health 1997, 1:287-294.

76. Poveda G, Rojas W, Quiñones ML, Vélez ID, Mantilla RI, Ruiz D, Zuluaga JS, Rua GL: Coupling between annual and ENSO timescales in the malariaclimate association in Colombia. Environ Health Perspect 2001, 109:489-493.

77. Herrera S, Suarez M, Sanchez G, Quiñones M, Herrera M: Uso de la técnica inmunoradiométrica (IRMA) en Anopheles de Colombia para la identificación de esporozoitos de Plasmodium. Colomb Med 1987, 18:2-6.

78. Durnez L, Van Bortel W, Denis L, Roelants P, Veracx A, Trung HD, Sochantha T, Coosemans M: False positive circumsporozoite protein ELISA: a challenge for the estimation of the entomological inoculation rate of malaria and for vector incrimination. Malar J 2011, 10:195.

79. Sylla EH, Kun JF, Kremsner PG: Mosquito distribution and entomological inoculation rates in three malaria-endemic areas in Gabon. Trans $R$ Soc Trop Med Hyg 2000, 94:652-656.

80. Burkot TR, Graves PM: The value of vector-based estimates of malaria transmission. Ann Trop Med Parasitol 1995, 89:125-134.

81. Moreno JE, Rubio-Palis Y, Páez E, Pérez E, Sánchez V, Vaccari E: Malaria entomological inoculation rates in gold mining areas of Southern Venezuela. Mem Inst Oswaldo Cruz 2009, 104:764-768.

82. Girod R, Gaborit P, Carinci R, Issaly J, Fouque F: Anopheles darlingi bionomics and transmission of Plasmodium falciparum, Plasmodium vivax and 
Plasmodium malariae in Amerindian villages of the upper-Maroni Amazonian forest, French Guiana. Mem Inst Oswaldo Cruz 2008, 103:702-710.

83. Soares LH, Alves FP, Zieler H, Salcedo JMV, Durlacher RR, Cunha RPA, Tada MS, Camargo LMA, Camargo P, Pereira-da-silva LH, Gil SHS: Seasonal

malaria transmission and variation of anopheline density in two distinct endemic areas in Brazilian Amazônia seasonal malaria transmission and variation of anopheline density in two distinct endemic areas in Brazilian Amazônia. Genetics 2003, 40:636-641.

doi:10.1186/1756-3305-6-61

Cite this article as: Naranjo-Diaz et al:: Abundance, behavior and

entomological inoculation rates of anthropophilic anophelines from a

primary Colombian malaria endemic area. Parasites \& Vectors 2013 6:61.

\section{Submit your next manuscript to BioMed Central and take full advantage of:}

- Convenient online submission

- Thorough peer review

- No space constraints or color figure charges

- Immediate publication on acceptance

- Inclusion in PubMed, CAS, Scopus and Google Scholar

- Research which is freely available for redistribution 